\title{
Use of Palm Oil Clinker in Concrete Research: A Review
}

\author{
Nur Farah Aziera Jamaludin¹, Khairunisa Muthusamy¹, Mohd Faizal Md Jaafar1', Fadzil Mat Yahaya1 \\ ${ }^{1}$ Faculty of Civil Engineering Technology, Universiti Malaysia Pahang, 26300 Pahang, Malaysia
}

\begin{abstract}
Palm oil clinker (POC) is a stone like by-product which is formed in the palm oil mill incinerator after extracted palm oil fibres and shells are burt to generate electricity for mill operation. The electricity is continuously generated. Then, the burnt fibres and shells are thrown at dumping areas as waste. This practice consumes a larger area at the landfills, causing environmental pollution. A review on the physical and chemical properties of POC was presented. The effect of using POC as lightweight aggregates and partial cement replacement on the mechanical properties of concrete produced was reviewed. The integration of suitable amount of POC as cement replacement and lightweight aggregates provided good workability and enhanced the concrete strength. Conclusively, this article has presented information regarding the development in POC concrete research, including the research gaps that remain to be filled.
\end{abstract}

ARTICLE HISTORY

Received: $10^{\text {th }}$ May 2021

Revised: $8^{\text {th }}$ June 2021

Accepted: $29^{\text {th }}$ June 2021

\section{KEYWORDS}

Construction materials

Environmental

Sustainability

Palm oil clinker

Concrete

\section{INTRODUCTION}

Worldwide, concrete is the most popular construction material [1]. The overall demand for concrete per year is 11.5 billion tonnes, consuming 9 billion tonnes of sand and rock, 1 billion tonnes of mixing water, and 1.5 billion tonnes of cement per year [2]. Concrete manufacturing is one of the human activities that has the greatest possible environmental effect, since it is the second most utilised material after water and requires a huge number of extracted materials [3]. Approximately up to $80 \%$ of concrete volume is made up of aggregates [4]. In 2019, the construction of sand and gravel supply resulted in about 970 million tonnes, which was a 4\% increase over in 2018 [5]. Demand for sand and gravel increased in 2019 due to continued growth in the private and public building sectors [5]. According to Kuhar [6], global demand for natural concrete aggregates is expected to rise at an average annual rate of $7.7 \%$ through 2022 , reaching 66.2 billion tonnes. These high levels of demand have affected the environment and living organisms [7]. According to Agrawal et al. [8], an unprecedented increase in demand for natural river sand had resulted in its erosion and extraction, which adversely influenced the climatic conditions, such as riverbank slippage and water table lowering. Additionally, mining will interrupt sediment supply and channel form, resulting in channel deepening (incision) and ecosystem sedimentation downstream. Instabilities in the channel and sedimentation caused by instream mining may also wreak havoc on public infrastructures, such as bridges, pipelines, and power lines [9]. Elimination of plants and degradation of the soil profile results in loss of ecosystems at both above and below levels. The decline in fauna population is one of the sand mining impacts [10]. At the same time, vast amounts of coarse aggregates are extracted from the surrounding quarries and have devastated environmental implications. Danielsen \& Kuznetsova [11] and Qin et al. [12] recorded environmental impacts on local neighbourhoods and communities like noise, pollution, atmospheric pollutants, such as heavy metals, methane $\left(\mathrm{CH}_{4}\right)$, nitrogen oxides $\left(\mathrm{NO}_{\mathrm{x}}\right)$, sulphur dioxide $\left(\mathrm{SO}_{2}\right)$, volatile organic compound $(\mathrm{VOC})$, carbon monoxide $(\mathrm{CO})$, and impacts on biodiversity due to land degradation. One of the most crucial development materials that is usually applied in nation constructions is Portland cement, which is used as a concrete binder. The cement industry is a major source of greenhouse gas emissions (GHGs), especially carbon dioxide $\left(\mathrm{CO}_{2}\right)$. As $\mathrm{CO}_{2}$ emissions continue to rise at an unprecedented rate, the predicted global warming by environmentalists over the last few decades has become a reality [13]. Gao et al. [14] estimated that cement manufacturing contributes to $5 \%-7 \%$ of total $\mathrm{CO}_{2}$ emissions into the atmosphere worldwide. Since concrete production accounts the most environmental issues, it is imperative to develop various mitigation strategies, especially by utilising waste materials to function as mixing ingredients in concrete.

Palm oil is a significant product which leads to many community livelihoods, governments' GDP, and achievement in several sustainable development goals (SDGs), including non-poverty, zero hunger, decent jobs, and economic growth [15]. Malaysia is the world's second largest palm oil producer after Indonesia, accounting for 26\% of global output [16]. Over the years, the number of operating palm oil mills has gradually increased. In 2020, Malaysia had 457 working mills with gross production capability of 1.16 million tonnes [17]. According to Malaysia Palm Oil Board (MPOB) [18], the total area under oil palm cultivation had grown to 5.90 million hectares in 2019, which was up $0.9 \%$ from 5.85 million hectares in the previous year. The growth in palm oil plantation areas, which also increases the quantity of palm oil processed, would lead to growth of profitless by-products generated from the industry. Palm oil industrial waste will rise as oil palm tree plantations increased [19, 20]. One hectare of oil palm plantation can produce about 50-70 tonnes of biomass residues [21]. The biomass produced by palm oil processing mills includes fibres, oil palm shells (OPS), palm oil fuel ash (POFA), palm oil clinker (POC), and empty fruit bunches (EFB), which could have catastrophic environmental consequences if not handled properly [22-24]. 
Following the oil extraction procedure, the pressed shells and fibres are burnt in an incinerator at a high temperature of about $850^{\circ} \mathrm{C}$, resulting in POC formation in the chamber, which is channelled out to the dumping sites [25]. The POC is a large grey chunk with an irregular and flaky shape that resembles a porous stone. Karim et al. [26] stated that due to its stable crystallographic structure, it is non-biodegradable under normal environmental conditions. The vast amount of waste generated is one of the key contributors to the nation's pollution issue [27] because these waste materials have little commercial value and are typically deposited into open fields and landfills after palm oil extraction [28, 29]. This irresponsible disposal triggers severe water, air, and land pollutions [30], including soil contamination, and affects the source of groundwater supplies [31]. According to Nayaka et al. [32] and Hamada et al. [33], POC is a waste material with many silica oxide $\left(\mathrm{SiO}_{2}\right)$ contents that can be turned into future building materials. The usage of POC as an alternative material in building can reduce construction costs, while not imposing a significant strain on the climate. Numerous studies were conducted in various aspects of using POC as one of the mixing ingredients to manufacture more environmentally friendly concrete. This research paper looks at the properties of POC and concrete which were studied thus far.

\section{PROPERTIES OF PALM OIL CLINKER}

\section{Physical Properties of Palm Oil Clinker}

POC is a by-product of palm oil fibres and shells incineration. The colour of POC is blackish, while the shape is irregular, which is porous, light, and durable. It can be transformed into lightweight aggregate concrete. For this research, POC was obtained from a local palm oil factory. Due to its low specific gravity and internal porous structure, POC has been proposed by many researchers to be ideal for LWA in concrete [34]. Table 1 lists the characteristics of POC. The physical properties of aggregate must be known before mixing concrete to obtain a desirable mixture, such as size degradation, specific gravity, bulk density, moisture content, water absorption, fineness modulus, aggregate crushing value (ACV), aggregate impact value (AIV), and Los Angeles abrasion value. The crushing value is crucial because it determines the aggregate load resistance. In road and pavement applications, concrete aggregates must have a crushing value of not more than $30 \%$, but up to $45 \%$ in other applications [35]. POC meets the requirements for a lightweight structural aggregate, according to the physical properties defined by different researchers. According to BSI Document 92/17688, lightweight aggregates have a specific gravity of less than 2.2 and a bulk density of less than $1200 \mathrm{~kg} / \mathrm{m}^{3}$. POC aggregate is about $25 \%$ lighter than river sand and $48 \%$ lighter than crushed granite stone in unit weight [36]. Furthermore, according to Hossain [37], POC is more water-absorbent than the standard aggregate. As a result, Al-Khaiat and Haque [38] concluded that when opposed to normal concrete aggregates, the impact of inadequate curing on porous lightweight concrete aggregates is negligible at the early stages of hydration. Excessive water usage and internal accumulation of lightweight aggregates aggravate this condition. Hardened concrete is aided because of the POC aggregate water absorption. POC aggregate has a crushing value of 6\%-10\% lower than crushed granite, allowing it to be used in any standardised shape. According to Mohammed et al. [39], the AIV and ACV were about 34\% and 30\% higher than granite aggregates, respectively. The POC aggregate higher ACV value may be attributed to the brittle and angular particle structure used in this study.

Table 1. Physical properties of POC

\begin{tabular}{|c|c|c|c|c|c|c|c|c|c|c|}
\hline Ref & $\begin{array}{c}\text { Type } \\
\text { of } \\
\text { waste }\end{array}$ & $\begin{array}{l}\text { Size } \\
\text { POC } \\
(\mathrm{mm})\end{array}$ & $\begin{array}{l}\text { Specific } \\
\text { Gravity } \\
\left(\mathbf{k g} / \mathbf{m}^{3}\right)\end{array}$ & $\begin{array}{c}\text { Bulk } \\
\text { Density } \\
\left(\mathbf{k g} / \mathbf{m}^{3}\right)\end{array}$ & $\begin{array}{c}\text { Moisture } \\
\text { Content } \\
(\%)\end{array}$ & $\begin{array}{c}\text { Water } \\
\text { Absorption } \\
(\%)\end{array}$ & $\begin{array}{l}\text { Fineness } \\
\text { Modulus }\end{array}$ & $\begin{array}{c}\text { ACV } \\
(\%)\end{array}$ & $\operatorname{AIV}(\%)$ & $\begin{array}{c}\text { Los } \\
\text { Angeles } \\
\text { Abrasion } \\
\text { Value } \\
(\%)\end{array}$ \\
\hline [39] & Coarse & $5-14$ & 1.82 & 781.08 & 0.07 & 4.35 & 6.75 & 18.08 & 25.36 & 27.09 \\
\hline [39] & Fine & $<5$ & 2.01 & 1118.86 & 0.11 & 26.45 & 3.31 & - & - & - \\
\hline [40] & Coarse & $5-14$ & 1.73 & 732 & $1 \pm 0.5$ & $3 \pm 2$ & - & 56.44 & - & - \\
\hline [41] & Coarse & $<10$ & 1.75 & 568 & 0.08 & 5.67 & - & - & 27.31 & 25.05 \\
\hline [42] & Coarse & $5-9$ & 1.76 & 801 & - & 6.08 & - & - & - & - \\
\hline [42] & Coarse & $9-14$ & 1.68 & 813 & - & 5.56 & - & - & - & - \\
\hline
\end{tabular}


Table 1. Physical properties of POC (cont.)

\begin{tabular}{|c|c|c|c|c|c|c|c|c|c|c|}
\hline Ref & $\begin{array}{l}\text { Type } \\
\text { of } \\
\text { waste }\end{array}$ & $\begin{array}{l}\text { Size } \\
\text { POC } \\
(\mathbf{m m})\end{array}$ & $\begin{array}{l}\text { Specific } \\
\text { Gravity } \\
\left(\mathbf{k g} / \mathbf{m}^{3}\right)\end{array}$ & $\begin{array}{c}\text { Bulk } \\
\text { Density } \\
\left(\mathbf{k g} / \mathbf{m}^{3}\right)\end{array}$ & $\begin{array}{c}\text { Moisture } \\
\text { Content } \\
(\%)\end{array}$ & $\begin{array}{c}\text { Water } \\
\text { Absorption } \\
(\%)\end{array}$ & $\begin{array}{l}\text { Fineness } \\
\text { Modulus }\end{array}$ & $\begin{array}{c}\text { ACV } \\
(\%)\end{array}$ & $\operatorname{AIV}(\%)$ & $\begin{array}{c}\text { Los } \\
\text { Angeles } \\
\text { Abrasion } \\
\text { Value } \\
(\%)\end{array}$ \\
\hline [43] & Coarse & $\begin{array}{l}4.75- \\
12.5\end{array}$ & 1.80 & 782 & - & 3.56 & 6.32 & - & - & - \\
\hline [44] & Fine & $<4.75$ & 2.15 & 811 & 0.11 & 5.75 & - & - & - & - \\
\hline [44] & Coarse & $\begin{array}{c}4.75- \\
10\end{array}$ & 1.81 & 732 & 0.28 & 4.35 & - & 56.44 & - & - \\
\hline [29] & Coarse & $\begin{array}{c}4.75- \\
9.5\end{array}$ & 1.88 & 732 & - & $3 \pm 2$ & - & 56.44 & - & - \\
\hline [31] & Fine & $<5$ & 2.15 & - & $\begin{array}{l}0.5 \pm \\
0.25\end{array}$ & $10 \pm 5$ & - & - & - & - \\
\hline [31] & Coarse & $5-14$ & 1.73 & - & $1 \pm 0.5$ & $3 \pm 2$ & & 56.44 & - & - \\
\hline [45] & Coarse & $<12$ & 1.69 & 860 & - & 7.0 & - & - & - & - \\
\hline [46] & Coarse & $5-12.5$ & 1.82 & 781.08 & - & 4.35 & 6.75 & - & 25.36 & 27.09 \\
\hline
\end{tabular}

\section{Chemical properties of POC}

Table 2 compares the chemical compositions of palm oil clinker powder (POCP) used in this study with those used in previous research. XRD is a technique that many researchers use to determine the amorphism of a substance [47]. The chemical composition findings were inconsistent, exhibiting heterogeneity as shown by the standard deviation in Table 2. $\mathrm{POC}$ is primarily composed of $\mathrm{SiO}_{2}, \mathrm{Al}_{2} \mathrm{O}_{3}, \mathrm{Fe}_{2} \mathrm{O}_{3}$, and $\mathrm{K}_{2} \mathrm{O}$. The active $\mathrm{SiO}_{2}$ is essential to demonstrate pozzolanic action [48]. Pozzolanic occurrence is likely to occur when the combined weight of three oxides $\left(\mathrm{SiO}_{2}, \mathrm{Al}_{2} \mathrm{O}_{3}\right.$, and $\left.\mathrm{Fe}_{2} \mathrm{O}_{3}\right)$ exceeds 70\%. Most samples produce these oxides more than 70\% [49]. The chemical composition of POCP varies according to the feeding ratio in boiler, boiler burning temperature and working conditions, including the geological state of the regions in which the palm oil trees were planted [22].

Table 2. Chemical properties of POC

\begin{tabular}{cccccccccccc}
\hline $\mathrm{Ref}$ & $\mathrm{SiO}_{2}$ & $\mathrm{~K}_{2} \mathrm{O}$ & $\mathrm{CaO}$ & $\mathrm{P}_{2} \mathrm{O}_{5}$ & $\mathrm{MgO}$ & $\mathrm{Fe}_{2} \mathrm{O}_{3}$ & $\mathrm{Al}_{2} \mathrm{O}_{3}$ & $\mathrm{SO}_{3}$ & $\mathrm{Na}_{2} \mathrm{O}$ & $\mathrm{TiO}_{2}$ & $\mathrm{LOI}$ \\
\hline$[43]$ & 59.63 & 11.66 & 8.16 & 5.37 & 5.01 & 4.62 & 3.7 & 0.73 & 0.32 & 0.22 & - \\
{$[50]$} & 65.4 & 9.519 & 5.744 & 6.563 & 6.402 & 2.713 & 1.947 & 0.635 & 0.318 & 0.113 & - \\
{$[51]$} & 55.39 & 17.7 & 7.05 & 3.97 & 2 & 10.81 & - & 0.19 & - & - & 0.02 \\
{$[33]$} & 65.30 & 13.65 & 3.89 & 0.78 & 3.72 & 5.65 & 4.23 & 0.09 & - & 0.13 & 2.42 \\
{$[32]$} & 60.29 & 7.24 & 3.28 & 3.78 & 4.20 & 4.71 & 5.83 & 0.31 & 0.20 & 0.10 & 5.23 \\
{$[26]$} & 63.90 & 10.20 & 6.93 & - & 3.37 & 3.30 & 3.89 & 0.21 & - & - & - \\
{$[52]$} & 59.9 & 15.1 & 6.37 & 3.47 & 3.30 & 6.93 & 3.89 & 0.39 & - & - & 1.89 \\
{$[48]$} & 60.29 & 7.79 & 3.27 & 3.10 & 3.76 & 4.71 & 5.83 & 0.11 & - & 0.13 & - \\
\hline
\end{tabular}


Table 2. Chemical properties of POC (cont.)

\begin{tabular}{cccccccccccc}
\hline Ref & $\mathrm{SiO}_{2}$ & $\mathrm{~K}_{2} \mathrm{O}$ & $\mathrm{CaO}$ & $\mathrm{P}_{2} \mathrm{O}_{5}$ & $\mathrm{MgO}$ & $\mathrm{Fe}_{2} \mathrm{O}_{3}$ & $\mathrm{Al}_{2} \mathrm{O}_{3}$ & $\mathrm{SO}_{3}$ & $\mathrm{Na}_{2} \mathrm{O}$ & $\mathrm{TiO}_{2}$ & $\mathrm{LOI}$ \\
\hline$[53]$ & 60.0 & 12.0 & 8.0 & 5.0 & 5.0 & 4.0 & 4.0 & - & - & - & - \\
{$[34]$} & 59.63 & 11.66 & 8.16 & 5.37 & 5.01 & 4.62 & 3.7 & 0.73 & 0.32 & 0.22 & - \\
{$[44]$} & 60.29 & 7.79 & 3.26 & 3.10 & 3.76 & 4.71 & 5.83 & 0.11 & - & 0.13 & - \\
\hline
\end{tabular}

\section{WORKABILITY}

Workability is a critical trait that contributes significantly to concrete consistency. Generally, a slump test is used to determine workability. According to Mehta and Monteiro [35], lightweight concrete with a slump value of 50-75 mm performs similarly to the conventional concrete with a slump value of $100-125 \mathrm{~mm}$ in site use. Past researchers [43,44, 40] investigated the slump of concrete with varying percentages of POC in various concrete mixtures as coarse aggregates replacement. Based on Table, Abutaha et al. [44] studied the slump of concrete mixes with POC as aggregates in the production of high strength concrete. The study found that higher amount of POC, will achieve lower slump . Similarly, the slump decreased with increased percentage of POC aggregates [40]. It concluded that the physical properties of POC with its sharp broken edges, rough, porous, and flaky surface, has a larger surface area than granite. Also, concrete mixes with POC as coarse aggregates might be harsher and less cohesive as compared to the conventional concrete mix that affected the workability of concrete mix. As a result, the amount of additional paste required was increased to achieve an adequate level of workability [40]. Recently Hamada et al. [33], studied the improvement of concrete strength with different percentages of nano palm oil clinker powder (NPOCP) as cement replacement and full replacement of POC aggregates in concrete mixture. The workability increased because of the high silica content (63.21\%) of NPOCP and might be due to the smaller particle size of NPOCP to provide additional lubrication in the concrete mix. Other studies such as [52] concluded that the hydration of POC powder may be low at inititial age because it contains $60 \%$ of silica and dicalcium silicate $\left(\mathrm{C}_{2} \mathrm{~S}\right)$ due to presence of wollastonite. As a consequence, it is predicted that by increasing the percentage replacement of POC powder and superplasticiser to disperse the cement particle in the same proportion results in workability improvement $[44,52]$. On the other hand, there are researchers who reported that workability of concrete mixes remained with the target ranges, which were $150 \pm 25 \mathrm{~mm}$ [44] and $105 \pm 25 \mathrm{~mm}$ [40] slump when POC is replaced as a fine aggregates replacement. The fineness modulus of POC was 2.62, which was closed to fineness modulus of sand (2.87); the workability produces is comparable to non-POC mixes.

Table 3. Effects of POC on workability of concrete

\begin{tabular}{ccccc}
\hline Ref & POC content $(\%)$ & Type of waste & Size POC $(\mathbf{m m})$ & Slump (mm) \\
\hline$[43]$ & $0,25,50,75,100$ & Coarse & $4.75-12.5$ & $55,50,55,51,53$ \\
{$[53]$} & $0,5,10,15,20,25$ & Cement & $<5$ & $49,140,150,175,225$ \\
{$[44]$} & $0,20,40,60,80,100$ & Coarse & $4.75-10$ & $140,130,125,110,128,100$ \\
{$[44]$} & $0,20,40,60,80,100$ & Fine & $<4.75$ & $140,132,145,155,150,140$ \\
{$[33]$} & $0,10,20,30,40$ & Cement & $150 \mu \mathrm{m}$ & $84,103,130,132,140$ \\
{$[40]$} & $0,10,20,30,40,50,60,70,80,90,100$ & Coarse & $5-14$ & $90,82,80,69,55,50,40$ \\
{$[40]$} & $0,10,20,30,40,50,60,70,80,90,100$ & Fine & $<5$ & $90,92,100,95,100,102,105$ \\
\hline
\end{tabular}

\section{HARDENED PROPERTIES OF POC CONCRETE}

Realisation on the increasing use of natural resources such as river sand, granite aggregates and limestones from the environments for concrete production has open the door for thw discovery of POC to be used as an alternative material. The potential of POC to be used as partial cement replacement, sand replacement and coarse aggregates replacement in concrete has been explored by many researchers, as presented in Table 4 . 
Table 4. Mechanical properties of POC in concrete

\begin{tabular}{|c|c|c|c|c|c|c|}
\hline Ref & $\begin{array}{c}\text { POC content } \\
(\% 0\end{array}$ & $\begin{array}{c}\text { Type of } \\
\text { waste }\end{array}$ & $\begin{array}{l}\text { Compressive } \\
\text { strength }\end{array}$ & $\begin{array}{l}\text { Flexural } \\
\text { strength }\end{array}$ & $\begin{array}{l}\text { Splitting tensile } \\
\text { strength }\end{array}$ & $\begin{array}{l}\text { Modulus of } \\
\text { elasticity }\end{array}$ \\
\hline [40] & $\begin{array}{c}0,10,20,30,40 \\
50,60,70,80 \\
90,100\end{array}$ & Coarse & $\begin{array}{l}\text { Decreased all } \\
\text { replacement }\end{array}$ & - & - & - \\
\hline [40] & $\begin{array}{c}0,10,20,30,40 \\
50,60,70,80 \\
90,100\end{array}$ & Fine & $\begin{array}{l}\text { Decreased all } \\
\text { replacement }\end{array}$ & - & - & - \\
\hline [33] & $0,10,20,30,40$ & Cement & $\begin{array}{c}\text { Increased at } 10 \% \\
\text { replacement }\end{array}$ & - & - & - \\
\hline [44] & $\begin{array}{c}0,20,40,60,80 \\
100\end{array}$ & Coarse & $\begin{array}{l}\text { Decreased all } \\
\text { replacement }\end{array}$ & $\begin{array}{l}\text { Decreased all } \\
\text { replacement }\end{array}$ & $\begin{array}{l}\text { Decreased all } \\
\text { replacement }\end{array}$ & $\begin{array}{l}\text { Decreased all } \\
\text { replacement }\end{array}$ \\
\hline [44] & $\begin{array}{c}0,20,40,60,80 \\
100\end{array}$ & Fine & $\begin{array}{l}\text { Decreased all } \\
\text { replacement }\end{array}$ & - & $\begin{array}{c}\text { Increased at } 20 \% \\
\text { replacement }\end{array}$ & $\begin{array}{l}\text { Decreased all } \\
\text { replacement }\end{array}$ \\
\hline [53] & $\begin{array}{c}0,5,10,15,20 \\
25\end{array}$ & Cement & $\begin{array}{c}\text { Increased at } 15 \% \\
\text { replacement }\end{array}$ & $\begin{array}{c}\text { Increased at } 15 \% \\
\text { replacement }\end{array}$ & $\begin{array}{c}\text { Increased at } 15 \% \\
\text { replacement }\end{array}$ & $\begin{array}{c}\text { Increased at } 15 \% \\
\text { replacement }\end{array}$ \\
\hline$[34]$ & $\begin{array}{c}0,25,50,75 \\
100\end{array}$ & Coarse & $\begin{array}{l}\text { Increased all } \\
\text { replacement }\end{array}$ & - & - & $\begin{array}{l}\text { Increased all } \\
\text { replacement }\end{array}$ \\
\hline [42] & 100 & Coarse & $\begin{array}{l}\text { Increased at } 100 \% \\
\text { replacement }\end{array}$ & $\begin{array}{c}\text { Increased at } 100 \\
\text { replacement }\end{array}$ & $\begin{array}{l}\text { Increased at } 100 \\
\text { replacement }\end{array}$ & $\begin{array}{c}\text { Increased at } 100 \\
\text { replacement }\end{array}$ \\
\hline$[54]$ & $\begin{array}{c}0,5,10,15,20 \\
25\end{array}$ & Fine & $\begin{array}{c}\text { Increased at } 20 \% \\
\text { replacement }\end{array}$ & - & - & - \\
\hline [55] & $0,5,10$ & Fine & $\begin{array}{l}\text { Increased all } \\
\text { replacement }\end{array}$ & $\begin{array}{l}\text { Increased all } \\
\text { repacement }\end{array}$ & - & - \\
\hline
\end{tabular}

\section{Palm Oil Clinker Powder as Partial Cement Replacement in Concrete}

The current paper summarises the results of several major investigations in which compressive strength, flexural strength, splitting tensile strength and modulus of elasticty were estimated by using varying quantities of cement replacement. The integration of finely ground palm oil clinker powder as cement replacement [37, 53] enhanced the strength of concrete. Concrete with $10 \%$ of nano-sized palm oil clinker powder recorded higher than the control concrete at 28 days due to pozzolanic reaction [33]. Another research by Ahmmad et al. [53] reported that 15\% of POC powder was the optimum percentage to be used as partial cement replacement for producing concrete with enhanced strength in compressive strength, splitting tensile strength, flexural strength and modulus of elasticity, as illustrated in Figure 1 and Figure 2. This was the result of pozzolanic reaction between calcium hydroxide from the hydration process with silica from palm oil clinker powder in the presence of moisture. The chemical reaction formed secondary calcium silicate hydrate gel, which contributed to denser internal structure of concrete, making the concrete to exhibit higher strength. The POC aggregates hahad different structures and produced tiny pores, ranging in size from 10.4 to $1200 \mu \mathrm{m}$ [25] and many pores with less than minimum sand particle size, which was $75 \mu \mathrm{m}$. In addition, the particle size of POC powder used was between $0.43 \mu \mathrm{m}$ and $112 \mu \mathrm{m}$. As a result, the smaller POC particles would fill voids within the pores of the coarse POC aggregates, and thus strengthening the bond [53]. Excessive amount of POC powder (exceed 15\% of replacement) produced more voids and resulted in decreased strength [53]. Several researchers have studied POC in semilightweight concrete [33] and lightweight concrete [53] as cement replacement; hence, the effectivenss of integrating POC as partial cement replacement in modern concrete, such as steel fibre reinforced concrete, porous concrete, geopolymer concrete, high strength concrete, pervious concrete and self compacting concrete, remain to be explored. The effect of different sizes of POC that range from micro to nano size as partial cement replacement towards durability and fire resisntance of concrete is amongst the interesting areas to venture. The resistance concrete that contains finely ground POC as partial cement replacement exposed to marine environment should be investigated. 


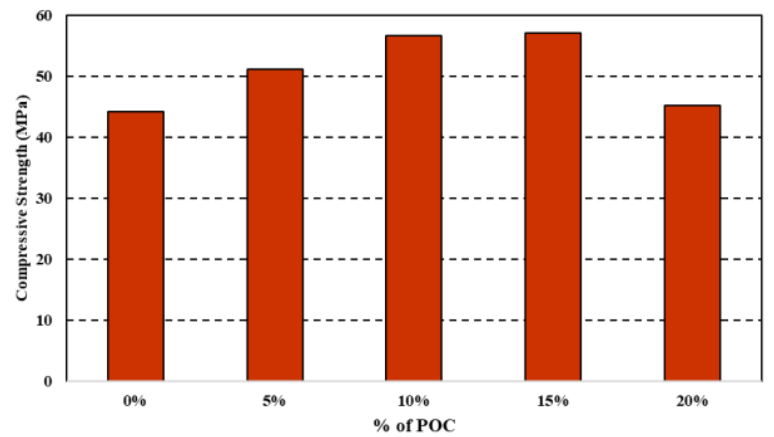

Figure 1. Compressive strength of POC as cement replacement from past researcher [53]

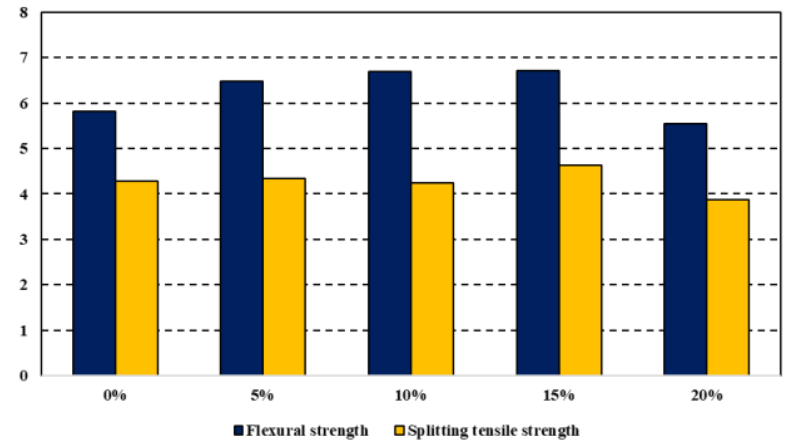

Figure 2. Flexural strength and tensile strength of POC as cement replacement [53]

\section{Palm Oil Clinker as Lightweight Aggregate in Concrete}

Several researchers $[40,44,34,42,56]$ have conducted POC as the coarse aggregates replacement in concrete mixes. POC concrete showed a similar trend of flexural strength, splitting tensile strength and modulus of elasticity as in the compressive strength. Abutaha et al. [40, 44] reported that by substituting coarse aggregates for POC at 0\%, 20\%, 40\%, $60 \%, 80 \%$, and $100 \%$ reduced compressive strength, flexural strength, splitting tensile strength and modulus of elasticity (MOE) at 28 days after curing. The strength reduced caused by POC aggregates integration and the predicted failure mode occurred primarily in the POC aggregates, according to similar findings for POC concrete [52]. Then, irregular shape and high porosity of POC coarse aggregates had a significant effect on the strength of the concrete. Reduction of strength can also be explained by the POC ACV. ACV of POC was 56.44\% higher than normal granite, which was $17.93 \%$. This finding indicated that the POC aggregates did not have an adequate load-bearing capacity because the highly porous and honeycombed structure of POC accelerated load distribution, resulting in a rapid decrease in load. POC is notorious for its fragility, as shown by the higher crushing value, which reduced aggregate load retention and concrete strength. The stiffness and volume of the POC used also affected the MOE. The MOE of lightweight aggregates concrete is usually 10 to $24 \mathrm{GPa}$ or $50 \%$ to $75 \%$ of the MOE of normal concrete [57]. High strength palm oil clinker concrete mixes have MOE values of 30 to $38 \mathrm{GPa}$, which is around $7 \%$ to $26 \%$ less than normal-weight concrete, according to Abutaha et al. [44]. The MOE value decreased as POC quantity in concrete increased. The study concluded that POC aggregates have a lower elastic modulus than regular aggregates because they are brittle. This pattern is close to the findings of Ozbakkaloglu et al. [58]. The MOE of a lightweight aggregates is determined by its pore structure and surface texture, as well as its density, according to Steven H. Kosmatka and Beatrix Kerkhoff [56]. Therefore, as compared to a porous aggregate, a thick aggregate with closely spaced pores has a higher MOE and a higher degree of hardness in concrete.

However, Ahmmad et al. [34] conducted their research by incorporating POC as a replacement of OPS as lightweight coarse aggregates in concrete mixes at $25 \%, 50 \%, 75 \%$ and $100 \%$ of replacement.The compressive strength was reported in the range of 43.52 and $63.20 \mathrm{MPa}$ at the age of 56 days and a mixture of $100 \%$ POC replacement has a maximum MOE of approximately $34.8 \mathrm{GPa}$. The strength was higher than the MOE obtained in previous studies in high strength lightweight concrete [59,60], which was significant in the design of structural elements in serviceability limit states. $100 \%$ replacement OPS by POC as coarse aggregates in concrete mixes recorded the highest strength to other replacements in compressive strength and MOE. This was because POC aggregates strengthened concrete bonding by allowing binders to enter the pores and strengthen the bond with the aggregates. They also reported that the cement content of $466 \mathrm{~kg} / \mathrm{m}^{3}$ was lower but can produce higher strength as compared to some previous studies. Application of $100 \%$ POC as replacement of oil palm shell (OPS) in concrete reduced the the cost of high strength lightweight concrete significantly due to lower cement content. In addition, researcher [42] also conducted investigation by adding palm oil fuel ash (POFA), ground granulated blast furnace slag (GGBS) and metakolin (MK) as binders and POC and OPS as aggregates in geopolymer concrete. The highest compressive strength, flexural strength, splitting tensile strength and MOE was recorded at $100 \%$ POC as coarse aggregates with sizes (9-14 $\mathrm{mm})$ as compared to OPS geopolymer concrete. POC was categorised as porous aggregates so the concrete was less vulnerable to inadequate curing than normal weight concrete due to the preserved water flow inside the porous aggregates and also increased the stiffness and the bond with cement paste which increased the concrete strength [42].

POC aggregate is porous in structure and lightweight as compared to the normal weight. This means that it is possible to use POC aggregates to improve the energy efficiency of buildings by demonstrating better insulation. In such a way, the effect of POC aggregates towards thermal conductivity and fire resistance of lightweight concrete is relevant to bring up in future studies. However, further research in POC as coarse aggregates with fixed mix proportion but from different source should be explored to investigate the effect of different POC sources will influence the mechanical and durability properties of lightweight aggregate concrete. 


\section{Palm Oil Clinker as Fine Aggregate in Concrete}

On the other hand, Abutaha et al. [40, 44] conducted a research by incorporating POC as filler in high strength concrete. Incorporation of POC as filler at $0 \%, 10 \%, 20 \%, 30 \%, 40 \%, 50 \%, 60 \%, 70 \%, 80 \%, 90 \%$, and $100 \%$ resulted in a slight decrease in compressive strength but was just $8 \%-17 \%$ less than control concrete [44]. The strength was maintained due to a substantial decrease in void ratio, which brought the strength similar to that of normal sand. Additionally, POC fine and natural sand particles had the same packing structure at equivalent size fractions, resulting in a reduction in substantial void formation. On the other hand, Arunima et al. [54] conducted their research in utilising POC as a partial replacement material for fine aggregates at $0 \%, 5 \%, 10 \%, 15 \%, 20 \%$ and $25 \%$ replacement. An increase in compressive strength was observed with the addition of POC to the mix until the optimum level of replacement, which was $20 \%$ of POC at 7 days and 28 days, whereas with POC content that exceeded $20 \%$, the strength of concrete decreased substantially with reduction in cohesion governed by POC, as shown in Figure 4. It might also be due to low absorption properties of POC which could leave excess water in concrete, causing excessive bleeding at higher POC content and resulted in the formation of internal voids and capillary channels in the concrete. This caused a reduction in its strength. Recently, Shahreen et al. [55] reported that the compressive strength and flexural strength increased in all replacements, as illustrated in Figure 3 and Figure 4. Inclusion of fine POC as partial replacement of sand concrete started the pozzolanic reaction and densification of concrete matrix, and thus improved interfacial bond between paste and aggregates. This study also confirmed that rougher particles of fine aggregates produced less voids in mineral aggregates and also contributed to the higher density which increased the stability of concrete mixture [55].

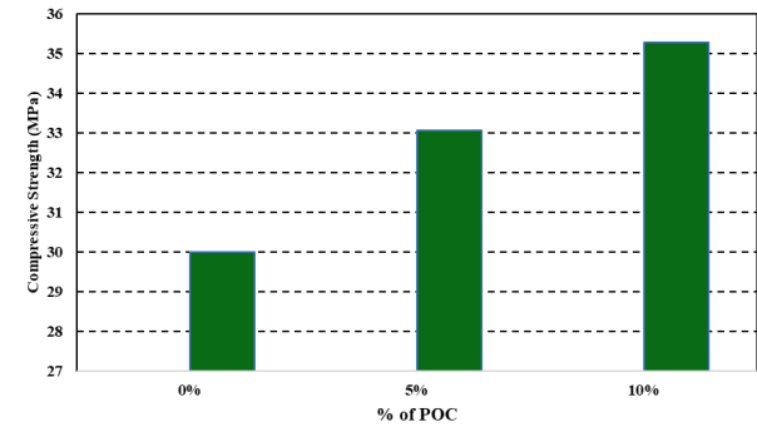

Figure 3. Compressive strength of POC as fine aggregate replacement [55]

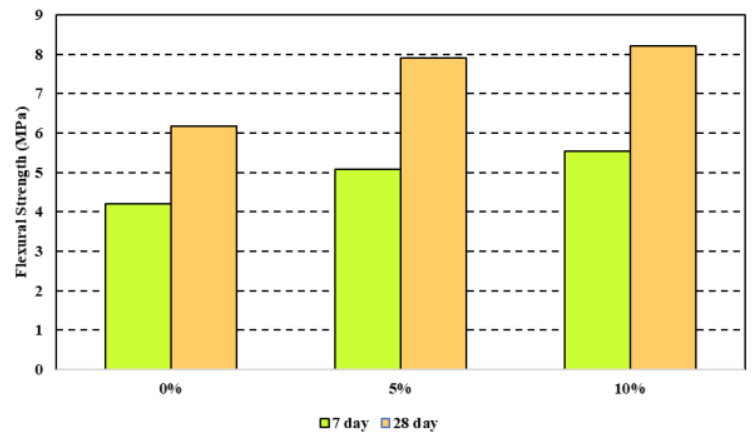

Figure 4. Flexural strength of POC as fine aggregate replacement at 7 and 28 days [55]

\section{CONCLUSION}

POC has excellent potential as a building material. POC is also suitable for use as a construction material, like coarse and fine aggregates as well as cement, due to its physical and mechanical properties. More research is needed in the future to determine the best combination for achieving the highest strength of this material in concrete applications. Utilisation of POC in the production of various types of concrete material would reduce quantity of natural resources consumed for concrete manufacturing and limits the amount of POC which is disposed as environmental polluting waste.

\section{ACKNOWLEDGEMENT}

The authors are thankful to Universiti Malaysia Pahang for financial support through the following financial grant PGRS200386.

\section{REFERENCES}

[1] M. Uysal and V. Akyuncu, "Durability performance of concrete incorporating Class F and Class C fly ashes," Constr. Build. Mater., vol. 34, pp. 170-178, 2012.

[2] K. Thunga and T. V. Das, "An experimental investigation on concrete with replacement of treated sea sand as fine aggregate," Mater. Today Proc., vol. 27, pp. 1017-1023, 2020.

[3] V. Torres de Sande, M. Sadique, P. Pineda, A. Bras, W. Atherton, and M. Riley, "Potential use of sugar cane bagasse ash as sand replacement for durable concrete," J. Build. Eng., vol. 39, no. February, p. 102277, 2021.

[4] Z. C. Steyn, A. J. Babafemi, H. Fataar, and R. Combrinck, "Concrete containing waste recycled glass, plastic and rubber as sand replacement," Constr. Build. Mater., vol. 269, p. 121242, 2021.

[5] USGS, “Construction sand and gravel data sheet," USGS Miner. Commod. Summ. 2020, vol. 1, no. 703, pp. $2019-2020$, 2020.

[6] M. Kuhar, "World Aggregates Market," SEMCO Publ., pp. 2-4, 2014.

[7] UNEP, "Sand, rarer and one thinks," UNEP Glob. Environ. alert Serv., vol. 2012, no. March, pp. 1-15, 2014. 
[8] U. S. Agrawal, S. P. Wanjari, and D. N. Naresh, "Impact of replacement of natural river sand with geopolymer fly ash sand on hardened properties of concrete," Constr. Build. Mater., vol. 209, pp. 499-507, 2019.

[9] M. A. Ashraf, M. J. Maah, I. Yusoff, and A. Wajid, "Sand mining effects, causes and concerns : A case study from Bestari Jaya , Selangor , Peninsular Malaysia,” vol. 6, no. 6, pp. 1216-1231, 2011.

[10] P. S. Pitchaiah, "Impacts of Sand Mining on Environment-A Review," Int. J. Geoinformatics Geol. Sci., vol. 4, no. 1, pp. 16, 2017.

[11] S. W. Danielsen and E. Kuznetsova, "Environmental Impact and Sustainability in Aggregate Production and Use," Eng. Geol. Soc. Territ. - Vol. 5 Urban Geol. Sustain. Plan. Landsc. Exploit., no. September, pp. 1-1400, 2015.

[12] Z. Qin, Q. Chen, X. Ji, S. Ming, and Q. Du, "Biodiversity protection and ecological restoration of Guilin Karst quarry," E3S Web Conf., vol. 194, p. 04025, 2020.

[13] J. A. Bhat, "Mechanical behaviour of self compacting concrete: Effect of wood ash and coal ash as partial cement replacement," Mater. Today Proc., vol. 42, pp. 1470-1476, 2020.

[14] T. Gao, L. Shen, M. Shen, F. Chen, L. Liu, and L. Gao, "Analysis on differences of carbon dioxide emission from cement production and their major determinants," J. Clean. Prod., vol. 103, pp. 160-170, 2015.

[15] L. M. Ayompe, M. Schaafsma, and B. N. Egoh, "Towards sustainable palm oil production: The positive and negative impacts on ecosystem services and human wellbeing," J. Clean. Prod., vol. 278, p. 123914, 2021.

[16] H. Mohammadhosseini, A. S. M. Abdul Awal, and J. B. Mohd Yatim, "The impact resistance and mechanical properties of concrete reinforced with waste polypropylene carpet fibres," Constr. Build. Mater., vol. 143, pp. 147-157, 2017.

[17] MPOB, "Number and Capacities of Palm Oil Sectors October 2020 (Tonnes/Year)," vol. 2020, no. October, p. $2020,2020$.

[18] MPOB, "Overview of the Malaysian Oil Palm Industry,” no. January, pp. 1-6, 2020.

[19] K. Adebayo Mujedu, M. A. Ab-Kadir, and M. Ismail, "A review on self-compacting concrete incorporating palm oil fuel ash as a cement replacement," Constr. Build. Mater., vol. 258, p. 119541, 2020.

[20] A. M. Zeyad, M. A. Megat Johari, B. A. Tayeh, and M. O. Yusuf, "Pozzolanic reactivity of ultrafine palm oil fuel ash waste on strength and durability performances of high strength concrete," J. Clean. Prod., vol. 144, pp. 511-522, 2017.

[21] Salathong J. The sustainable use of oil palm biomass in Malaysia with Thailand's comparative perspective. See also: http://www.wiaps.waseda.ac.jp/ initiative/2006/intern/group_02/PDF/Jessada\%20Salathong.pdf; 2007.

[22] J. Kanadasan, A. F. A. Fauzi, H. A. Razak, P. Selliah, V. Subramaniam, and S. Yusoff, "Feasibility studies of palm oil mill waste aggregates for the construction industry," Materials (Basel)., vol. 8, no. 9, pp. 6508-6530, 2015.

[23] S. K. Loh, "The potential of the Malaysian oil palm biomass as a renewable energy source," Energy Convers. Manag., vol. 141, pp. 285-298, 2017.

[24] N. Afzanizam, M. Nazri, M. Jaafar, and J. Ng, "Progress in biomass gasi fi cation technique - With focus on Malaysian palm biomass for syngas production," vol. 62, pp. 1047-1062, 2016.

[25] R. Ahmmad, M. Z. Jumaat, S. Bahri, and A. B. M. S. Islam, "Ductility performance of lightweight concrete element containing massive palm shell clinker," Constr. Build. Mater., vol. 63, pp. 234-241, 2014.

[26] M. R. Karim, H. Hashim, H. Abdul Razak, and S. Yusoff, "Characterization of palm oil clinker powder for utilization in cement-based applications," Constr. Build. Mater., vol. 135, pp. 21-29, 2017.

[27] M. Hazim, M. Amini, R. Hashim, N. Syuhada, O. Sulaiman, and M. Ezwan, "Glutardialdehyde modified starch from waste oil palm trunks as a binder for wood composite making,” vol. 104, no. April 2020, 2021.

[28] T W. Tangchirapat, T. Saeting, C. Jaturapitakkul, K. Kiattikomol, and A. Siripanichgorn, "Use of waste ash from palm oil industry in concrete," Waste Manag., vol. 27, pp. 81-88, 2007.

[29] H. A. Ibrahim and H. Abdul Razak, "Effect of palm oil clinker incorporation on properties of pervious concrete," Constr. Build. Mater., vol. 115, pp. 70-77, 2016.

[30] A. N. Mohammed et al., "Improving the Engineering and Fluid Transport Properties of Ultra-High Strength Concrete Utilizing Ultrafine Palm Oil Fuel Ash,” J. Adv. Concr. Technol., vol. 12, pp. 127-137, 2014

[31] J. Kanadasan and H. A. Razak, "Mix design for self-compacting palm oil clinker concrete based on particle packing," Mater. Des., vol. 56, pp. 9-19, 2014.

[32] R. R. Nayaka, U. J. Alengaram, M. Z. Jumaat, S. B. Yusoff, and M. F. Alnahhal, "High volume cement replacement by environmental friendly industrial by-product palm oil clinker powder in cement e lime masonry mortar," J. Clean. Prod., vol. 190, pp. 272-284, 2018.

[33] H. M. Hamada, A. A. Alattar, F. M. Yahaya, K. Muthusamy, and B. A. Tayeh, "Mechanical properties of semi-lightweight concrete containing nano-palm oil clinker powder," Phys. Chem. Earth, no. January, p. 102977, 2021.

[34] R. Ahmmad, M. Zamin, U. J. Alengaram, S. Bahri, and M. Abdur, "Performance evaluation of palm oil clinker as coarse aggregate in high strength lightweight concrete," J. Clean. Prod., vol. 112, pp. 566-574, 2016.

[35] P. K. Mehta and P. J. M. Monteiro, "Microstructure, Properties and Materials," Proc. 2nd Int. Conf. Model. Simulation, ICMS2009, vol. 7, pp. 537-540, 2009.

[36] D. C. L. Teo, A. Mannan, and J. V Kurian, "Flexural Behaviour of Reinforced Lightweight Concrete Beams Made with Oil Palm Shell ( OPS ),” J. Adv. Concr. Technol., vol. 4, no. 3, pp. 459-468, 2006.

[37] K. M. A. Hossain, "Properties of volcanic pumice based cement and lightweight concrete," Cem. Concr. Res., vol. 34, no. August 2003, pp. 283-291, 2004. 
[38] H. Al-Khaiat and M. N. Haque, "Effect of Initial Curing On Early Strength and Physical Properties of A Lightweight Concrete," Cem. Concr. Res., vol. 28, no. 6, pp. 859-866, 1998.

[39] B. S. Mohammed, W. L. Foo, and M. Abdullahi, "Flexural strength of palm oil clinker concrete beams," Mater. Des., vol. 53, no. 16, pp. 325-331, 2014.

[40] F. Abutaha, H. Abdul Razak, and J. Kanadasan, "Effect of palm oil clinker (POC) aggregates on fresh and hardened properties of concrete," Constr. Build. Mater., vol. 112, pp. 416-423, 2016.

[41] K. Muthusam, J. Mirza, N. A Zamri, M. W. Hussin, A. P. P. Abdul Majeed, A. Kusbiantoro and A. M. Albshir Budiea, "Properties of high strength palm oil clinker lightweight concrete containing palm oil fuel ash in tropical climate," Constr. Build. Mater., vol. 199, pp. 163-177, 2019.

[42] S. M. A. Kabir, U. J. Alengaram, M. Z. Jumaat, S. Yusoff, A. Sharmin, and I. I. Bashar, "Performance evaluation and some durability characteristics of environmental friendly palm oil clinker based geopolymer concrete," J. Clean. Prod., vol. 161, pp. 477-492, 2017.

[43] M. Z. Jumaat, U. J. Alengaram, R. Ahmmad, S. Bahri, and A. B. M. S. Islam, "Characteristics of palm oil clinker as replacement for oil palm shell in lightweight concrete subjected to elevated temperature," Constr. Build. Mater., vol. 101, pp. 942-951, 2015

[44] F. Abutaha, H. A. Razak, H. A. Ibrahim, and H. H. Ghayeb, "Adopting particle-packing method to develop high strength palm oil clinker concrete,” Resour. Conserv. Recycl., vol. 131, no. February, pp. 247-258, 2018.

[45] M. Aslam, P. Shafigh, M. Alizadeh Nomeli, and M. Zamin Jumaat, "Manufacturing of high-strength lightweight aggregate concrete using blended coarse lightweight aggregates," J. Build. Eng., vol. 13, no. February, pp. 53-62, 2017.

[46] M. N. Huda, M. Z. Bin Jumat, and A. B. M. S. Islam, "Flexural performance of reinforced oil palm shell \& palm oil clinker concrete (PSCC) beam," Constr. Build. Mater., vol. 127, pp. 18-25, 2016.

[47] M. Sow, J. Hot, C. Tribout, and M. Cyr, "Characterization of Spreader Stoker Coal Fly Ashes (SSCFA) for their use in cementbased applications," Fuel, vol. 162, pp. 224-233, 2015.

[48] M. R. Karim, H. Hashim, and H. Abdul Razak, "Assessment of pozzolanic activity of palm oil clinker powder," Constr. Build. Mater., vol. 127, pp. 335-343, 2016.

[49] ASTM C618. (2014). Standard Specification for Coal Fly Ash and Raw or Calcined Natural Pozzolan for Use. 1-5.

[50] A. Mohammed Babalghaith, S. Koting, N. H. Ramli Sulong, M. R. Karim, and B. Mohammed AlMashjary, "Performance evaluation of stone mastic asphalt (SMA) mixtures with palm oil clinker (POC) as fine aggregate replacement," Constr. Build. Mater., vol. 262, p. 120546, 2020.

[51] A. H. Ismail, A. Kusbiantoro, S. C. Chin, K. Muthusamy, M. Islam, and K. F. Tee, "Pozzolanic reactivity and strength activity index of mortar containing palm oil clinker pretreated with hydrochloric acid," J. Clean. Prod., vol. 242, p. 118565, 2020.

[52] H. A. Ibrahim, H. Abdul Razak, and F. Abutaha, "Strength and abrasion resistance of palm oil clinker pervious concrete under different curing method," Constr. Build. Mater., vol. 147, pp. 576-587, 2017.

[53] R. Ahmmad, U. J. Alengaram, M. Zamin, N. H. R. Sulong, M. O. Yusuf, and M. Abdur, "Feasibility study on the use of high volume palm oil clinker waste in environmental friendly lightweight concrete," Constr. Build. Mater., vol. 135, pp. 94-103, 2017.

[54] V. R. Arunima and S. Sreelekshmi, "Effects on Compressive Strength on Using Palm Oil Clinker as Partial Replacement of Fine Aggregate in Concrete," Int. J. Sci. Res., vol. 5, no. 6, pp. 815-817, 2016.

[55] E. S. Ab Wahab, R. Omar, S. F. Che Osmi, N. A. Muhamad Khairussaleh,A. Abdullah., "Preliminary study on Mechanical Properties of Concrete added with Fine Palm Oil Clinker," Jordan Eng. Assoc. Conf., 2012.

[56] S. H. Kosmatka, B. Kerkhoff, and W. C. Panarese, Design and Control of Concrete Mixtures. 2008.

[57] T. A. Holm and T. W. Bremner, "State-of-the-Art Report on High-Strength, High-Durability Structural Low-Density Concrete for Applications in Severe Marine Environments," US Army Corps Eng. Eng. Res. Dev. Center, ERDC/SL TR-00-3, no. January 2000, 2000.

[58] T. Ozbakkaloglu, L. Gu, and A. Fallah Pour, "Normal- and high-strength concretes incorporating air-cooled blast furnace slag coarse aggregates: Effect of slag size and content on the behavior," Constr. Build. Mater., vol. 126, pp. 138-146, 2016.

[59] J. Gao, W. Sun, and K. Morino, "Mechanical properties of steel fiber-reinforced, high-strength, lightweight concrete," Cem. Concr. Compos., vol. 19, no. 4, pp. 307-313, 1997.

[61] O. Kayali, M. N. Haque, and B. Zhu, "Some characteristics of high strength fiber reinforced lightweight aggregate concrete," Cem. Concr. Compos., vol. 25, no. 2, pp. 207-213, 2003. 